\title{
The Estimation of Acyclovir in Bulk and Tablet Dosage form by Using Specificity and Analytical Method Development
}

\section{Sudam G Mule*, Narendra G Patre, Ajay D Kshirsagar and Seema B Kharwade}

D.K. Patil Institute of Pharmacy, MH, India

*Corresponding Author: Sudam G Mule, D.K. Patil Institute of Pharmacy, MH, India. DOI: $10.31080 /$ ASPS.2022.06.0856
Received: January 11, 2022

Published: February 18, 2022

(C) All rights are reserved by Sudam G Mule., et al.

\section{Abstract}

A selective, accurate, HPLC method was developed by this study for the determination of Acyclovir in bulk and tablet dosage form. This method was developed by Thermo Fisher Scientific Software Chromquest Version 4.1 using C18 column in solvents 700 ml of Acetonitrile and $300 \mathrm{ml}$ of buffer pH $3.0 \pm 0.10$ 70:30) HPLC grade were set, C8 (4.6 mm x $1.5 \mathrm{~cm}, 5 \mu \mathrm{m})$ column, flow rate $0.50 \mathrm{ml} /$ min as mobile phase. the mobile phase was pumped, and the sample was detected at $254 \mathrm{~nm}$. For standard Acyclovir the retention time was $5 \mathrm{~min}$. The method was validated for analytical standards such as linearity, accuracy, precision, and robustness. In a wide range of $5-25(\mu \mathrm{g} / \mathrm{ml})$ the linearity was observed.

Keywords: Acyclovir; Specificity; Reagent

\section{Introduction}

Category Acyclovir drug belongs to Antiviral Dru (Nucleoside RT inhibitors) Acyclovir is an antiviral agent and act against herpes viruses. Chemical Name of drug 2-Amino-1,9-dihydro-9-( (2hydroxyethoxy)methyl)-3H-purin-6-one with Molecular formula $\mathrm{C}_{8} \mathrm{H}_{11} \mathrm{~N}_{5} \mathrm{O}_{3}$. It is a purine nucleoside analogue, used as antiviral agent against herpes viruses. It is mainly used for the treatment of herpes simplex virus infections, chickenpox and shingles. For herpes virus infections the administered dose for immuno-suppressed patients is up to $10 \mathrm{mg} / \mathrm{kg}$ body weight every $8 \mathrm{~h}$. Structure of Acyclovir as shown in figure 1.

\section{Material and Methods}

- Chemicals and reagents: This method was developed by Thermo Fisher Scientific Software Chromquest Version 4.1 using C18 column in solvents $700 \mathrm{ml}$ of Acetonitrile and 300 $\mathrm{ml}$ of buffer $\mathrm{pH} 3.0 \pm 0.10$ as mobile phase. The drug Acyclovir was obtained as gift sample of drug: Swapnroop Drugs and Pharmaceuticals, Aurangabad-431003 India. As the mobile phase. $700 \mathrm{ml}$ of Acetonitrile and $300 \mathrm{ml}$ of buffer $\mathrm{pH} 3.0 \pm$ 0.10 (70:30) buffer used as mobile phase. Before injecting the drug, to acquire the saturation the column was equilibrated with mobile phase of stationary phase

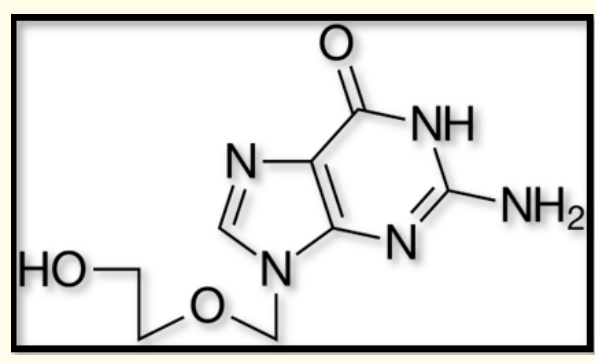

Figure 1: Structure of Acyclovir.

- Mobile Phase Preparation: To make a buffer solution to dissolved $3.4 \mathrm{~g}$ of potassium dihydrogen phosphate in $500 \mathrm{ml}$ of HPLC grade water adjusted $\mathrm{pH}$ of this solution to $3.4 \pm 0.10$ with orthophosphoric acid sonicated for 5 minutes and filtered through $0.45 \mu$ filter paper. So that mobile Phase taken $700 \mathrm{ml}$ of Acetonitrile and $300 \mathrm{ml}$ of buffer $\mathrm{pH} 3.0 \pm 0.10$ (70:30) sonicated for $5 \mathrm{~min}$.

- Selection of Analytical UV Wavelength ( $\lambda$ max): To fix wavelength for analysis the prepared stock solution was scanned in ultraviolet spectroscopy over the range of 200-800 $\mathrm{nm}$ from 
resultant spectrum wavelength at $254 \mathrm{~nm}$ was chosen as in this range maximum absorption of drug occurs. So, this range is taken to analyze the sample.

- Preparation of Standard Stock Solution of Acyclovir: $100 \mathrm{mg}$ of Acyclovir was weighed accurately and transferred into the $100 \mathrm{ml}$ flask, diluted with mobile phase. The resulted concentration of solution is $1 \mathrm{mg} / \mathrm{ml}$

- Preparation of Sample: $1 \mathrm{ml}$ of stock solution is diluted with $100 \mathrm{ml}$ of mobile phase to get concentration $10 \mu \mathrm{g} / \mathrm{ml}$.

\section{Results and Discussion}

\section{Method development}

The method was developed by $700 \mathrm{ml}$ of Acetonitrile and $300 \mathrm{ml}$ of buffer $\mathrm{pH} 3.0 \pm 0.10$ as a high concentration in mobile phase yield tailing in the peak due to the presence of water in the buffer. During method development, a number of variations have been done with mobile phase in different concentration and $0.50 \mathrm{ml} / \mathrm{min}$ flow rate to give asymmetric peak.

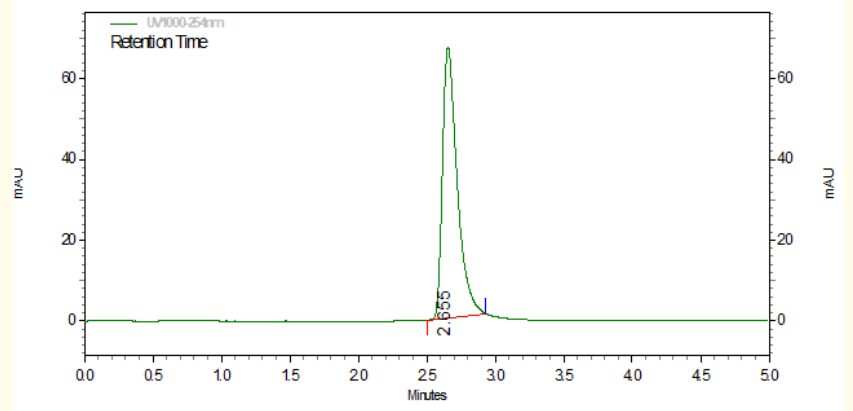

Figure 2: Chromatogram of Acyclovir.

\section{Validation}

\section{Linearity}

The different concentration varies from $5-30 \mu \mathrm{g} / \mathrm{ml}$ were prepared Chromatograms were recorded by injecting $20 \mu \mathrm{l}$ from each concentration of the solution. All estimation were carried out at triplicate for each concentration. As shows in table 1 calibration: linearity and range of Acyclovir.

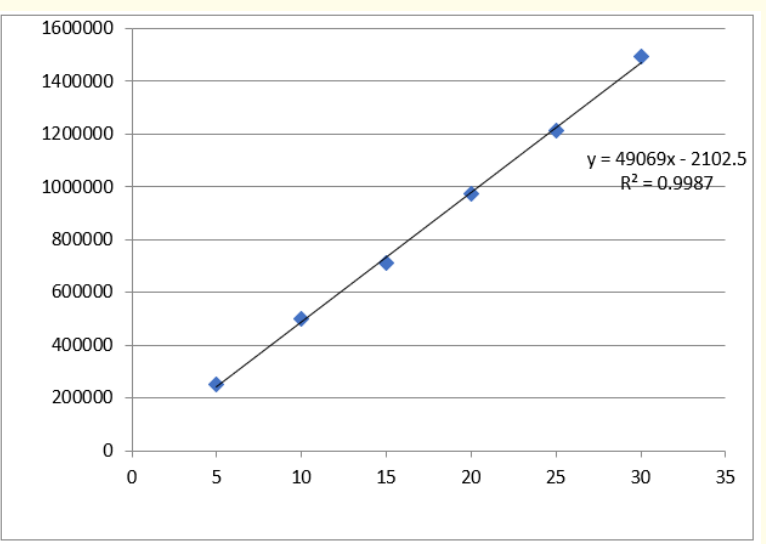

Figure 3: Linearity Curve and range for Acyclovir.

\begin{tabular}{|c|c|c|}
\hline Sr No & Concentration $\mu \mathrm{g} / \mathrm{ml}$. & Area \\
\hline 1 & 5 & 252394 \\
\hline 2 & 10 & 500095 \\
\hline 3 & 15 & 712399 \\
\hline 4 & 20 & 972894 \\
\hline 5 & 25 & 1210151 \\
\hline 6 & 30 & 1491666 \\
\hline
\end{tabular}

Table 1: Linearity and range of Acyclovir.

Precision

Intraday precision

The intraday precision was determined by analyzing standard solution of Acyclovir at three different concentrations in the concentration range 17,22 , and $27 \mu$ for three times on the same day Each concentration was applied in triplicate and \% RSD was calculated.

Interday precision

The intraday precision was determined by analyzing standard solution of Acyclovir at three different concentrations in the concentration range 17,22 , and $27 \mu$ for three times on three different days. Each concentration was applied in triplicate and \% RSD was calculated. 


\begin{tabular}{|c|c|c|c|c|}
\hline $\begin{array}{c}\text { Concentration } \\
(\mu \mathrm{g} / \mathrm{ml} .)\end{array}$ & Area & $\begin{array}{c}\text { Average } \\
\text { Area }\end{array}$ & SD & $\%$ RSD \\
\hline \multirow{3}{*}{17} & 874071 & \multirow{3}{*}{878604} & \multirow{3}{*}{3801.60} & \multirow{3}{*}{0.431} \\
\hline & 883375 & & & \\
\hline & 878368 & & & \\
\hline \multirow{3}{*}{22} & 1145932 & \multirow{3}{*}{1145399} & \multirow{3}{*}{388.90} & \multirow{3}{*}{0.033} \\
\hline & 1145015 & & & \\
\hline & 1145250 & & & \\
\hline \multirow{3}{*}{27} & 1327744 & \multirow{3}{*}{1335462} & \multirow{3}{*}{8594.79} & \multirow{3}{*}{0.643} \\
\hline & 1347453 & & & \\
\hline & 1331189 & & & \\
\hline
\end{tabular}

Table 2: Intraday precision of Acyclovir.

\begin{tabular}{|c|c|c|c|c|}
\hline $\begin{array}{c}\text { Concentration } \\
(\mu \mathrm{g} / \mathrm{ml} .)\end{array}$ & Area & $\begin{array}{c}\text { Average } \\
\text { Area }\end{array}$ & S D & \%RSD \\
\hline \multirow{3}{*}{17} & 874071 & \multirow{3}{*}{879742} & \multirow{3}{*}{4332.99} & \multirow{3}{*}{0.492} \\
\hline & 880567 & & & \\
\hline & 884588 & & & \\
\hline \multirow{3}{*}{22} & 1145932 & \multirow{3}{*}{1145648} & \multirow{3}{*}{384.54} & \multirow{3}{*}{0.033} \\
\hline & 1145105 & & & \\
\hline & 1145909 & & & \\
\hline \multirow{3}{*}{27} & 1327744 & \multirow{3}{*}{1366761} & \multirow{3}{*}{16716,59} & \multirow{3}{*}{1.223} \\
\hline & 1391827 & & & \\
\hline & 1380714 & & & \\
\hline
\end{tabular}

Table 3: Inter day precision of Acyclovir.

\section{Robustness}

The robustness of an analytical procedure is a measure of its capacity to remain unaffected by small but deliberate variation in the analytical procedure parameters. To evaluate HPLC method robustness a few parameters were deliberately varied. The parameters included variation in flow rate and change in the wavelength.

\section{Assay of acyclovir}

Avg. wt. of 10 tablets $=0.6970 \mathrm{~g}$ Brand name- Zoster 400 DTMfd. By- Leeford Heathcare Ltd.LC: $400 \mathrm{mg}$. Weighed 10 tablets, crushed and powder equivalent to $100 \mathrm{mg}$ of Acyclovir was weighed, added $50 \mathrm{ml}$ of mobile phase, sonicated and diluted to $100 \mathrm{ml}$ with it. Solution was filtered to get clear solution. $1 \mathrm{ml}$ of above solution was diluted to $100 \mathrm{ml}$ with mobile phase. Avg wt of 10 tablet $=0.6970 \mathrm{~g}$ Label claim $=400 \mathrm{mg}$.

\begin{tabular}{|c|c|c|c|c|}
\hline Wavelength & Area & $\begin{array}{c}\text { Average } \\
\text { area }\end{array}$ & S D & $\%$ RSD \\
\hline \multirow{3}{*}{$252 \mathrm{~nm}$} & 650052 & \multirow{3}{*}{650754} & \multirow{3}{*}{498.60} & \multirow{3}{*}{0.076} \\
\hline & 651055 & & & \\
\hline & 651157 & & & \\
\hline \multirow{3}{*}{$256 \mathrm{~nm}$} & 651307 & \multirow{3}{*}{651272} & \multirow{3}{*}{208.40} & \multirow{3}{*}{0.031} \\
\hline & 651509 & & & \\
\hline & 651001 & & & \\
\hline
\end{tabular}

Table 4: Change in Wavelength $\pm 2 \mathrm{~nm}$.

\begin{tabular}{|c|c|c|c|c|}
\hline Flow rate & Area & $\begin{array}{c}\text { Average } \\
\text { area }\end{array}$ & S D & \% RSD \\
\hline \multirow{3}{*}{$0.4 \mathrm{~min} / \mathrm{ml}$} & 657068 & \multirow{3}{*}{656666} & \multirow{3}{*}{432.81} & \multirow{3}{*}{0.062} \\
\hline & 656866 & & & \\
\hline & 656065 & & & \\
\hline \multirow{3}{*}{$0.6 \mathrm{~min} / \mathrm{ml}$} & 651792 & \multirow{3}{*}{651157} & \multirow{3}{*}{496.49} & \multirow{3}{*}{0.076} \\
\hline & 651099 & & & \\
\hline & 650580 & & & \\
\hline
\end{tabular}

Table 5

\begin{tabular}{|c|c|c|c|c|c|c|}
\hline $\begin{array}{c}\text { Sr } \\
\text { No }\end{array}$ & $\begin{array}{c}\text { Name of } \\
\text { Drug }\end{array}$ & $\begin{array}{c}\text { Label } \\
\text { claim }\end{array}$ & $\begin{array}{c}\text { Peak } \\
\text { Area }\end{array}$ & $\begin{array}{c}\text { Concentration } \\
\text { of drug in } \mathbf{\mu g} / \\
\mathbf{m l} \text {.) }\end{array}$ & $\begin{array}{c}\text { \% drug } \\
\text { contetns }\end{array}$ & $\begin{array}{c}\text { \% } \\
\text { RSD }\end{array}$ \\
\hline 1 & Acyclovir & $400 \mathrm{mg}$ & 627561 & $10 \mu \mathrm{g} / \mathrm{ml}$. & $98.5 \%$ & 0.21 \\
\hline
\end{tabular}

Table 6: Assay of Acyclovir.

\section{Accuracy (recovery studies)}

10 tablets were powdered and mixed. This powder was then spiked with a quantity Acyclovir corresponding to 50\%, 100\% and $150 \%$ of the labelled claim. Each of these powder mixtures was analyzed in triplicate and the quantity of Acyclovir was determined using calibration equation. Accuracy was reported as \% Acyclovir recovered.

\section{Conclusion}

The proposed RP-HPLC method is simple, sensitive, precise and accurate. Since the analysis is completed within 5 --minutes, it clearly indicates that the method is rapid and thus it could be for routine analysis of Acyclovir from bulk drug and its tablet dosage forms [1-17]. 


\begin{tabular}{|c|c|c|c|c|}
\hline $\begin{array}{c}\text { Spike } \\
\text { concentration }\end{array}$ & $\begin{array}{c}\text { Spike } \\
\text { solution } \\
\text { area }\end{array}$ & $\begin{array}{c}\text { Std } \\
\text { Solution } \\
\text { area }\end{array}$ & $\begin{array}{c}\text { Recovery } \\
\text { in }(\boldsymbol{\mu g} / \\
\mathbf{m l})\end{array}$ & $\begin{array}{c}\% \\
\text { Recovery }\end{array}$ \\
\hline $50 \%$ & 867763 & 580095 & 149.59 & $99.7 \%$ \\
\hline $100 \%$ & 1169853 & 580095 & 201.66 & $100.8 \%$ \\
\hline $120 \%$ & 1282591 & 580095 & 221.10 & $100.5 \%$ \\
\hline
\end{tabular}

Table 7: Recovery of Acyclovir.

\section{Conflicts of Interest}

Nil.

\section{Bibliography}

1. H J Schaeffer., et al. "9- (2- Hydroxyethoxymethyl) guanine activity against viruses of the herpes group". Nature 272.5654 (1978): 583-585.

2. Swart KJ., et al. "Automated high-performance liquid chromatographic method for the determination of acyclovir in plasma". Journal of Chromatography A 663.1 (1994): 65-69.

3. S Ashok Reddy., et al. "Spectrophotometric determination and validation of Acyclovir". Archives of Applied Science Research 3.1 (2011): 328-332.

4. G Holkar., et al. "Method Validation and Quantitative determination of antiviral drug Acyclovir in human plasma by a LCMS/ MS". Biological Forum- An International Journal 4.1 (2012): 1117.

5. H Mascher., et al. "New, high-sensitivity high-performance liquid chromatographic method for the determination of Acyclovir in human plasma, using fluorometric detection". Journal of Chromatography 583 (1992): 122-127.

6. P Nebinger and M Koel. "Determination of acyclovir by ultra filtration and high performance liquid chromatography". Journal of Chromatography B: Biomedical Sciences and Applications 619.2 (1993): 342-344.

7. Gurdeep R Chatwal and Sham K Anand. "Instrumental Methods of Chemical Analysis (Analytical Chemistry)”. pg: 2.5662.567 .

8. Douglas A Skoog., et al. "Principles of instrumental analysis, Saunders Golden Sun burst Series". Philadelphia, $2^{\text {nd }}$ edition (1980): 725-760.

9. Stulzer HK., et al. "Development and validation of an RP-HPLC method to quantitate acyclovir in cross-linked chitosan microspheres produced by spray drying". Journal of Chromatography Science 46.6 (2008): 496-500.
10. Basavaiah K., et al. "Simple high-performance liquid chromatographic method for the determination of acyclovir in pharmaceuticals". Il Farmaco 58.12 (2003): 1301-1306.

11. Arnal J., et al. "Biowaiver Monographs for Immediate Release Solid Oral Dosage Forms: Aciclovir". Journal of Pharmaceutical Sciences 97 (2008): 5061-5073.

12. https://en.wikipedia.org/wiki/Aciclovir\#/media/ File:Aciclovir_2D_structure.svg

13. Tzanavaras PD and Themelis DG. "High-throughput HPLC assay of acyclovir and its major impurity guanine using a monolithic column and a flow gradient approach". Journal of Pharmaceutical and Biomedical Analysis 43.4 (2007): 1526-1530.

14. Manoharan G. "High-pressure liquid chromatographic method development and validation for estimation of Acyclovir in raw and tablet formulation". Scholars International Journal of Chemistry and Material Sciences 1.1 (2018): 1-5.

15. International Conference on Harmonization of technical Requirements for Registration of Pharmaceuticals for Human use, ICH Harmonized Tripartite guideline-Validation of Analytical procedures: Text and methodology Q2 (R1), Current step 4 version., London (2005).

16. Seema B Kharwade and Narendra G Patre. "Method Development, Validation and Stability Indicating Studies of Rifabutin Using HPLC-DAD". Acta Scientific Pharmaceutical Sciences 5.11 (2021).

17. Gunasekar Manohara., et al. "Development and Validation of a Stability-Indicating RP-HPLC Method for the Estimation of Acyclovir, in Bulk and Ointment Dosage Form". International Journal of Pharmaceutical and Phytopharmacological Research (eIJPPR) 9.1 (2019): 11-18.

\section{Assets from publication with us}

- Prompt Acknowledgement after receiving the article

- Thorough Double blinded peer review

- Rapid Publication

- Issue of Publication Certificate

- High visibility of your Published work

Website: www.actascientific.com/

Submit Article: www.actascientific.com/submission.php Email us: editor@actascientific.com

Contact us: +919182824667 